\title{
Lactobacilli as Probiotics and their Isolation from Different Sources
}

\author{
Farhatul-Ain Arshad1 ${ }^{*}$, Rubaida Mehmood ${ }^{2}$, Dr. Saqib Khan², Dr. Rubina ${ }^{1}$, Sajid Hussain², Dr. Annus \\ Khan $^{3}$ and Dr. Omar Farooq ${ }^{3}$
}

${ }^{1}$ Department of Zoology, Women University Multan, Multan, Punjab, Pakistan

${ }^{2}$ Multan Institute of Nuclear Medicine and Radiotherapy (MINAR), Nishtar Hospital, Multan, Pakistan

${ }^{3}$ Anhui Medical University, China

${ }^{*}$ Corresponding author: Farhatul-Ain Arshad, Department of Zoology, Women University Multan, Multan, Punjab, Pakistan, Tel: +92-3356298784; E-mail: rai_farhat@yahoo.com

Received Date: September 07, 2018; Accepted Date: September 25, 2018; Published Date: September 30, 2018

Copyright: (C) 2018 Arshad F, et al. This is an open-access article distributed under the terms of the Creative Commons Attribution License, which permits unrestricted use, distribution, and reproduction in any medium, provided the original author and source are credited.

Citation: Arshad F, Mehmood R, Hussain S, Khan MA, Khan MS (2018) Lactobacilli as Probiotics and their Isolation from Different Sources. Br J Res 5 (3): 43.

\section{Abstract}

Probiotics play a pivotal role in health maintenance and prevention of many disorders. They are microbial feed supplements that confer the health effect on the host. Probiotics protects the body itself from infection, especially gastrointestinal tract. Acidophilus is a probiotic microorganisms that have a beneficial effect on the host. Lactobacilli acidophilus are "friendly" bacteria that normally live in our digestive, urinary and genital systems without causing disease. The therapeutic benefits have been investigated in women having vaginal and urinary tract infections. In this review, we studied about previous 15 years articles in which the isolation of Lactobacilli bacteria from different sources was mentioned. It has been found that they may be isolated from fruits and vegetables, human stool culture, natural antimicrobial agent, cheese, kefir grains, dairy and non-dairy products, fermented and raw milk, feces of breast fed infants, lactating milk, sheep, buffalo and cow milk, yogurt, beverages, poultry sources, animal rumen contents, pengging duck's caecum, chicken intestine and fecal samples, chicken feed, enzymes, fermented rice, curd, meat and yeast extracts, glucose and sucrose, human gut, human colonial epithelial cells, human and animal vagina and mouth extraction, diapers of human babies, pineapples wastes, industrial sausages, ice-cream, small intestines of piglets, corn slurry, crop and intestinal ducks. Hence the paper reviews the current scenario of isolation of Lactobacilli from different sources, their proposed mechanisms and health benefits for human beings along with their future perspectives.

Keywords: Lactobacilli; Probiotics; Supplements; Health benefits; Antimicrobial agents

\section{Introduction}

L. acidophilus is a probiotics, microorganisms that exert a beneficial effect on the host. Recent studies investigate that some species that produce hydrogen peroxide have been found in normal vaginal flora. Consequently, the beneficial products have been investigated in women with urinary and vaginal tract infections while its value in treating lower urinary tract infections remains unclear. It has also been used to cure sore mouth caused by Candida infections [1].

Lactobacillus is a species of friendly bacteria that live normally in our digestive, urinary, and genital systems without causing disease. It is also found in some fermented foods like yogurt and in dietary supplements [2].

Lactobacilli preserve the natural balance and maintenance of natural stability of micro flora present in the intestines of chickens. They reduce the body and serum fat contents and develop the better poultry performance. They can also be used in the form of supplements as an alternative for antibiotics [3].

Valuable effects deliberated by Lactobacilli include the inhibition of pathogenic organisms such as Salmonella, Shigella and Helicobacter. Furthermore, Lactobacilli have been associated with various other health benefits e.g., enhanced immune response and lactose intolerance reduction. A beneficial role for Lactobacilli has also been obscure in colon cancer [8]

Lactobacilli boost-up the immune system and treat Cancer, Canker sores, Fever blisters, Hives, General digestion problems. Necrotizing enter colitis (NEC) in babies born prematurely. High cholesterol, sensitivity to milk (lactose-intolerance), Common cold, preventing infections in people on ventilators, Lyme disease [4].

Probiotics: Probiotic term derived from Greek word Pro (favor) and bios (life). They can be advantageous for its host by improving the microbial balance in the gut tract [5] and are nonpathogenic bacteria that has a beneficial health effect on adequate quantity consumption in their host [6].

Probiotics are followers of the commensally bacteria present in the gastrointestinal tract of animals and human. A great number of lactic acid bacteria (LAB) were obtained from various naturally fermented foods [9]. Various $L A B$, particularly strains of 
recognized as security (GRAS) microorganisms have been shown to have healthy beneficial functions [7]. Breast milk is the best food for infants not only because it justifies all the required nutrients but also protects the new born against many infectious diseases [10]. Moreover it contains probiotic substances that influences the growth of the beneficial bacteria in the neonatal gut $[10,11]$. In a general view human breast milk contains carbohydrate, fat, protein, minerals and microbiologically point of view; it is really an essential factor in the development, initiation and composition of the neonatal gut micro flora (Martin et al.). Daily consumption of $800 \mathrm{ml}$ breast milk, infant ingests approximately $1 \times 10^{5}-1 \times 10^{7}$ commensal bacteria [11-13]. Lactobacilli considered most attractive probiotic organisms in human milk $[11,14]$ (Table 1 ).

Table 1 Definitions of `probiotics.

\begin{tabular}{|l|l|l|}
\hline Sr. No & Published Definitions & References \\
\hline 1 & $\begin{array}{l}\text { Probiotics are the "live microorganisms that confer a health benefit on the host when available in adequate quantity." The most } \\
\text { frequently used as probiotics agents are the lactic acid bacteria i.e., Enterococcus and ifidobacterium sp. and antibiotic- } \\
\text { resistant, nonpathogenic, ascosporic yeasts i.e., Saccharomyces boulardii. }\end{array}$ \\
\hline 2 & $\begin{array}{l}\text { Probiotics being a live microbial feed supplement improves host's intestinal microbial balance. Most commonly, acidophilus, } L . \\
\text { casei, Bifidobacteriumbifidum, B. longum and the east Saccharomyces boulardii have been used as probiotics in humans. }\end{array}$ \\
\hline [17,18]
\end{tabular}

Table no. 1 explained the most proposed definitions of probiotics by different authors as probiotics are living microorganisms that are beneficial for human as well as animal's health that are naturally occurring in the body. Their supplements can also be used as an alternative of antibiotics.

\section{Lactobacilli}

Lactobacilli help in maintenance of natural balance of micro flora in the intestines as well as healthy digestive system. The focus on the use of Lactobacilli has following reasons: (1) Lactobacilli exhibit "competitive exclusion", (2) Lactobacilli easily adhere to the epithelial cells of intestine and (3) Lactobacilli influence the immune system and also recognize as safe symbionts with the host [3].

The microbial antagonism applied by Lactobacilli has promoted their use for protection of the intestinal and vaginal mucosae. The prominence of lactobacilli in the human vaginal microbiota was noted as early as 1892 , by Doderlein. The $\mathrm{pH}$ of the vagina is 4 , which is inhibitory to most microorganisms associated with vaginal pathology these microflora protects vagina from urinogenital infections [15].

\section{Lactobacilli in Different Food Stuffs}

To comprehend the emerging needs of supplements, probiotics used in health food industry moreover many investigations are focusing on probiotics potential $L A B$ isolation from different resources of fermented milk, foods, Taiwanese pickled cabbage and feces of breast-fed infants [19-23].

Hoque et al showed that in the food industry, LAB is broadly used as starter cultures and has been quoted to be part of human microbiota. In dairy products such as cheeses, yoghurts and fermented milks and raw milk, Lactobacilli are naturally present to generate a health profit for the consumer or can be used as supplements. The isolation of Lactobacilli from different sources and their proposed mechanism in our body are shown in the table below (Table 2 ).

Table 2 Numerous studies have reviewed about the isolation of Lactobacilli from different sources and have their various beneficial effects on the body of organisms.

\begin{tabular}{|c|c|c|}
\hline Target source and Media & Properties & $\begin{array}{l}\text { Referenc } \\
\text { es }\end{array}$ \\
\hline Apple, Grape and Banana (MRS agar) & $\begin{array}{l}\text { - Lactobacilli is non-pathogenic and save to use with the status of General Recognize as Safe } \\
\text { (GRAS), bile tolerant, acid resistant, and produce antimicrobial substances that are biologically } \\
\text { active protein. } \\
\text { - LAB is used in the formation of food stuffs prepared by lactic fermentation such as fermented } \\
\text { vegetables, dairy products, sourdough bread and fermented meat. }\end{array}$ & [24] \\
\hline Stool culture of Human (MRS agar) & $\begin{array}{l}\text { - Lactobacilli due to their beneficial and effective role in the gut ecology; they are gaining more } \\
\text { attention in biomedical researches. } \\
\text { This organism is endowed with sets of genes essential for survival in GIT gastrointestinal tract, } \\
\text { interactions with other organisms in the gut, also with the host epithelial barrier and immune } \\
\text { system. } \\
\text { L. plantarum found in a variety of ecological environments is a well characterized probiotic } \\
\text { species. }\end{array}$ & [25] \\
\hline $\begin{array}{l}\text { Local Environment (raw and fermented dairy } \\
\text { products, sausages and silage) } \\
\text { (MRS and M17 agar) }\end{array}$ & $\begin{array}{l}\text { - Antimicrobial agents are of enormous value for combating infectious diseases. } \\
\text { - Have been tried not to use in treating gastrointestinal disease only, but also to use in food } \\
\text { industry as natural antimicrobial substances that many have a bacteriostatic or bacteriocidal } \\
\text { effect against many food borne pathogens. }\end{array}$ & [26] \\
\hline
\end{tabular}


Iranian Koozeh Traditional Cheese(MRS) broth and (brain heart infusion soft agar (BHI agar))
- Enhanced immune response, alleviation of symptoms of lactose intolerance, diarrhea treatment, serum cholesterol reduction, vitamin synthesis and anti-carcinogenic and anti-microbial activities.

- Constitute one of the most developed segments and represent a major branch of the functional foods industry.

- Cheese is an interesting food-based delivery vehicle of probiotics to the gastro-intestinal tract because of a higher $\mathrm{pH}$, fat content and solid consistency as compared to yoghurt.

- Considered a multi-functional starter culture in the food industry since they have been applied in various fermented systems such as bread, cheese and milk with very promising results.

- Can be successfully used in the treatment of vaginal infections, as they are able to produce a range of anti-microbial compound indicated by many studies.

- Successfully applied to a specific population suffering from lactose intolerance.

Kefir Grains

- Used in food products as probiotic organisms.

- Production and preservation of a many variety of fermented product.

glucose $(\mathrm{w} / \mathrm{v}), 1 \%$ yeast and $1 \%$ peptone)

- Having high phenotypic, genomic and metabolic diversity which shows its success in industrial application.

- Produce various compounds such as bacteriocins which can antagonize the growth of some pathogenic bacteria in foods.

- $\quad$ LAB has been successfully used in the treatment of acute infantile diarrhea and other diarrheal illnesses.

Raw milk

(MRS medium)

- Probiotics enhance good digestion, increase resistance to infection; boosts immune function, inhibit the harmful bacterial growth and favor the intestinal micro flora balance.

- In the research of strains with probiotic potential, for finding new probiotic strains for functional food products.

- Produce bile salt hydrolase (BSH) that helps to reduce serum cholesterol and hence BSH activity is also considered as an additional criterion for the selection of probiotics.

Dairy and non-dairy products (MRS agar)

Non-dairy and non-fermented beverages and foods such as fresh vegetables and fruits, human breast milk and feces of breast-fed infants.

(MRS agar)

Mammary areola, milk, and breast skin of 8 healthy mothers, oral swabs and feces of their respective breast-fed infants

(MRS agar)

Poultry sources (agar and broth MRS)

Probiotics offer an alternative to various antibiotics

- Can be one of the most effective therapies for the prevention of several disorders in the newly born infants.

- Play a beneficial role in the ecosystem of the human gastrointestinal (GI) tract.

- Protects the newborn against infectious diseases.

- Bacterial species able to produce lactic acid as a main end-product of the of carbohydrate fermentation.

- Widely used as probiotics in efforts to reduce the pathogen colony in the intestinal tract and to maintain a balanced microbiota.

- Improving the nutritional food value, improving digestion of lactose, controlling serum cholesterol levels, controlling gastrointestinal infections and controlling some types of cancer.

- Used in different medical and health-related areas including the treating infections during pregnancy; control of antibiotic related diarrhea control of intestinal inflammation; management of allergic diseases; and prevention of urinary tract infections.

Milk products

(MRS, M17 agar)

Reduce cholesterol level, stimulate the immune system and also able to stabilize the microflora of the gut.

- Include the most important groups of microorganisms usually used in food fermentations.

Plants and vegetable matrices (MRS agar and Kanamycin AesculinAzide agar)

- Inhibit the food Spoilage and contribute to the texture and taste of fermented products.

- Control of cholesterol level, prevention of anti-carcinogenic activity intestinal infections.

- Incorporated into foods for use as probiotics or functional foods.

- Commercially available in the form of powder, liquid, gel, paste, granules or even as capsules, sachets, etc.

Dairy Food Products and Animal Rumen Contents (MRS broth)

- Dairy isolates are capable of growing in the food processing conditions whereas rumen isolates are well adapted to grow in the gastro-intestinal tract (GIT) environment.

- Microorganisms with beneficial effects for human health.

- Many researchers have been conducted on the isolation and evaluation of probiotic potential bacteria and in turn establishment of a biobank to save them from destruction, for future applications in medicine and food industry.

- Confer a health benefit for the host.

Yogurt

(MRS agar)
- Boosting immune system, decreasing GIT infections, decreasing cholesterol level, cancer and diarrhea.

- May additionally provide nutrients e.g., calcium and protein. 
Dairy products
(MRS agar and broth)

- Help in activation of the immune system, prevention of carcinoma cell growth, maintenance of mucosal integrity.

- Presentation of an antagonistic environment for pathogens

- An increase of interest about the commercial utilization of strains isolated from traditional and naturally fermented dairy products, which possess health-promoting effects.

- Low $\mathrm{pH}$ and high concentration of bile salt is used in vitro to evaluate their potential as probiotic agent.

- Promotes the colonic environment by decreasing carcinogenic material, pathogenic bacteria, and improving immunity.

Duck's caecum (MRS media)

- Act as restrainer of the damage.

- Health of host animals by improving their intestinal balance and preventing ingested pathogens.

lleum and caeca of healthy 6 and 11 years chicken (MRS agar)

Healthy 6 and 11 years old chicken's Fecal sample (MRS agar)

Chicken feed from 2 broiler chicken

(MRS agar)

raditional dairy product "katak" (Potato Dextrose Agar (PDA))

- These microorganisms with a competitive advantage over the other species as an excellent probiotics.

- Help to maintain the chicken products and prevent economic losses.

- Important and major normal microbial population in chicken.

- Chicken's body weight, feed conversion ratio and egg weight in poultry improvement.

- Beneficial health of host animals and source of animal protein for humans.

- Ability to tolerate acid, bile and also adhere to the intestinal epithelium of the hosts.

- $\quad$ Filamentous moulds and yeasts are the main spoilage organisms of various products such as stored crops fermented dairy foods, bread, silage and feed hay.

- Possesses a strain-specific spectrum and mechanism of inhibitory activity against the different mould sand yeasts.

- Widely detected in several bacterial genera in the gastrointestinal microbiota of animals.

- Isolated from the intestines or feces from mammals, which are a natural environment rich in conjugated and unconjugated bile acids.

- Isolated from human and animal sources to maximize the likelihood of compatibility and to ensure their survival in the GIT.

Hydrolase (enzyme)Bile salts

- $\quad$ Represented by dairy products e.g., yogurts and fermented milks

MRS agar, M17 (Difco) agar (sheep milk)

- Sheep milk represents only $1.3 \%$ of total global milk production, but is mostly used for cheese production.

- Traditional fermented food products e.g., fermented rice are known to possess probiotic potential.

- Provide a myriad of health benefits.

MRS broth (fermented rice)

- Parameters tested in the assessment of potentially probiotic microbes.

- Increased interest in the role of probiotic bacteria in human health from the last 2 decades.

- Improve the intestinal microbial balance.

Fermented Milks and Yogurts

(human GIT)

Reduce or eliminate ailments i.e., colon irritation, constipation and diarrhea.

- $\quad$ Exert various health welfares beyond the inherent basic nutrition.

- Probiotics products contain at least $10^{7}$ living microbes per g.

- Reduce or eliminate ailments such as colon irritation, constipation and probiotic diarrhea

- Safe use in the dairy industry, beneficial effects by balancing the intestinal flora and ultimately competing with pathogens for gut colonization.

- Very good source for species.

MRS medium (curd)

- Potentially beneficial to the macrobiotic ecosystem of humans and other animals.

- Confer a health benefit on the host.

- Lactic acid and short-chain fatty acids contribute to several positive effects on the host.

- Decreased lactose intolerance, increased resistance to intestinal pathogenic bacterial species, enhanced immune system, increased bioavailability of minerals, positive action on lipid metabolism, and decreased risk of cardiovascular diseases intestinal infectious diseases, obesity, osteoporosis, some cancers and non-insulin-dependent diabetes.

Yogurt

(Dairy products) Yeast Azide Aesculin Agar(YAE), Kanamycin Aesculin Azide Agar (KAA) medium

- Use as a culture.

- May play an important role in determining cheese ripening and flavor development.

- Produce bacteriocins against pathogens or food spoilage bacteria.

- $\quad$ Protect the habitat from unwanted invaders.

Columbia blood agar plates, Yeast-cysteine blood agar plates, MRS agar plates.( vaginal and oral)

- Balance microbial flora.

The human body hosts various species in different anatomic regions having different interactions with the host: e.g. the oral cavity, the female genital tract and the intestines. 
MRS broth (pineapple waste) world production of tropical fruits.

- The economical production of nutrient rich culture medium could be achieved by using locally available agro wastes that are abundant in nutrients that meet the microbial requirement.

- Natural starter for fermented milk in Tibet, China.

Tibetan Kefir Grains (MRS and difco agar)

- A variety of health claims in addition to its nutritional value.

MRS broth (cocoa fermentation, fermented food cauim and industrial sausage.)

- Have been used as food supplements and are highly worthier for their probiotic properties.

- Numerous naturally fermented products from Brazil harbor lactic acid bacteria.

- Best feed for infants having all the nutritional requirement

- Protects the newly born infant against infectious diseases.

- Stimulate the growth of the beneficial bacteria in neonatal gut.

- The indigenous beneficial bacteria perform a fermentation process in which vegetables develop a pleasantly sour taste and remain rich in vitamins

- Restrain gut flora, reduce gastrointestinal syndrome, diminish diarrhea disease, soften an irritable bowel, and enhances the immune system, anti-food allergy, immunomodulatory activity, anti-mutagenic / anti-carcinogenic activity and cholesterol lowering effect.

Paocai (MRS media)

Curd (MRS media)

- Fermented foods with specially added active live cultures; such as in soy yogurt, or as dietary supplements.

- Commonly found in a diversity of ecosystems including human, animal, plants and soil.

- Help in the digestibility of complex carbohydrates such as indigestible fibers and benefit the human health.

Sweet potato (Sweet potato medium (SPM))

- Plays a major role in the food industry and human nutrition.

- Unsterile and can be contaminated with saprophytic and pathogenic microorganisms

- High antimicrobial activity against pathogenic (causing food toxics infections and toxemia) and saprophytic microorganisms.

- Ability to increase the natural defenses of the host against enter pathogens by the production of antimicrobial substances.

- Inhabits the oral cavity, gastrointestinal tract (GIT), skin, upper respiratory tract, vagina and the major part of this micro flora resides in human gut.

Fermented food (MRS broth)

- Sources for production of several extracellular enzymes for industrial applications.

- Widely used as starter cultures in several fermentation processes that been increasing globally

- Advantageous as these organisms are generally regarded as safe (GRAS) by the WHO.

- Exert health benefits to the consumer, other than those related to nutritional effects.

- The useful effect of probiotic bacteria to the host is related to its concentration in the lumen of the intestine.

Fermented milks (MRS media and broth)

- Grants a claim for health promotion

- Have been used in processing the fermented food for centuries.

- Fermented milk products i.e., yoghurt.

Yoghurt (Man Rogosa and sharp media (MRS) broth)

- Have an inhibitory activity against common human pathogens.

- Increasing interest in "health" foods in recent years has stimulated innovation and new product development in the food industry worldwide.

- Confer a health benefit in the host.

- May harbor resistance genes which may be transferred to pathogenic bacteria.

- Large variety of fields relevant for human and animal health

- Consists of different capsules, vitamins, enzymes, tablets or some fermented foods containing microorganisms which have beneficial effect on the health of host.

- Confer a health benefit on the host is accepted by FAO/WHO.

- Have been associated with various health benefits such as the reduction of lactose intolerance and increased immune response.

- Quantities confer a health benefit on the host.

- Resists the rigors of the human GIT and helps to improve the gut flora balance.

- Persist in the GIT influencing metabolic activities like cholesterol accumulation, lactose activity and vitamin production. agar, broth)

Fermented vegetables (brain heart infusion (BHI) agar medium, De Man Rogosa Sharpe (MRS) media and potato extrose agar (PDA) media and nutrient agar.)

Increase advantageous bacteria called "probiotics" in the intestinal tract.

- Ability to provide specific health benefits beyond their basic nutritional value

- Currently, the largest segment of the functional food market is conquered by healthy food. 
GI tract (agar dilution and broth microdilution, commercial methods, Etest, Minimal Inhibitory Concentration (MIC test,)
- Used as starter cultures in industrial food production, as well as in the production of probiotic products due to their potential health benefits to consumer.

- Potential of preventing the growth of intestinal pathogen bacteria e.g., salmonella

- Preserve and maintain the balance and natural stability of micro flora in the intestine of chickens.

- $\quad$ Reduce the number of Salmonella enteritidis and Clostridium perfringens in the treated chickens.

- Inhabits the oral cavity, skin gastrointestinal tract (GIT), upper respiratory tract, vagina and the major part of this microflora resides in human gut.

- Conferring numerous health benefits.

- Ability to adhere the epithelial cells and mucosal surfaces.

- Maintain the intestinal microbial balance.

- Recommended as food to provide for the balance of intestinal flora.

human milk (agar, TPY Trypticase Phytone Yeast agar and MRS-cysteine agar Man, Rogosa and Sharp MRS)

- Used for long time in food ingredients for human and also to feed animals without any side effects.

- Decreasing GIT infections, decreasing cholesterol level.

- Fermented food production quality.

- Naturally present or added intentionally, for technological reasons or to generate a health benefit for the consumer and yogurt is one of the best-known foods that contain probiotics.

- Exert health benefits (on their host) beyond inherent nutrition

Mammalian digestive tract

- Ferment a variety of nutrients primarily into lactic acid products constitutes a major functionally related group of enteric organisms.

- Implicated in a number of health promoting functions that affect general health and well-being of the host.

GI tract (MRS broth and the culture)

- Confer a health benefit on the host.

- At least $70 \%$ of the total bacteria are responsible for vaginal protection

Vagina (Chocolate agar MRS media MRS broth) Promoted their use for protection of the intestinal and vaginal mucosae.

Human stomach (man-ragosa sharp MRS agar)

The human stomach was considered to be microbiologically sterile because of factors including low $\mathrm{pH}$ and digestive enzymes.

- Strengthen the barrier function of the gut microflora and for a non-specific enhancement of the immune system.

- Maintain microbiota balance, preventing or remedying the appearance of gastrointestinal infections.

Small intestines of piglets (media MRS broth)

Vagina of healthy women (lactic agar and MRS broth)

- Used in the fermentation of food industry.

- Absence of these bacteria is related to the increase in the recurrent of urinary tract infections.

- Have protective effect against vaginal pathogenic species.

Vagina of healthy animals, intestines of jus slaughtered animals and the diapers of human babies (MRS broth)

Parmigiano Reggiano cheese (MRS agar)

- A wide range of products for human and animal nutrition have been produced over the past decades.

- Avoid misleading and health risks.

- Have been utilized in dairy products such as milk or yoghurt. Milk enhances its efficacy by providing lactose as a substrate.

- Contains some factor which influences cholesteremia in man

Maasai Yogurt (MRS media)

- A very large daily intake of fermented cow's milk lowers the level of serum cholesterol in men.

- Beneficial for growth promotion of farm animal, alleviation of lactose intolerance, protection from pathogens, relief of constipation, anti-cholesterolaemic effect and immune stimulation.

- Restore a healthy gut flora.

Corn slurry (MRS agar)

- Intestinal microbial ecosystem maintenance.

- Antimicrobial substances such as lactic acid and bacteriocins production

- Oral dosing of poultry with native gut micro-organisms prevents infections.

- Adherence to the mucosa and co-aggregation to form a barrier for preventing colonization by pathogens.

\section{Lactobacilli as Probiotics for the Cure of Disorders}

\section{Bio-therapeutic agents}

Lactobacilli work as a biotherapeutic agents in humans such as: treatment of vaginitis, diarrhea, and prevention of antibiotic- associated diarrhea, urinary tract infections (UTIs), lactosemal absorption, immune system stimulation, cholesterol reduction, and anti-mutagenic effects. As Cheplin HA et al, Alm L, et al and Graf W, [80-82] have favorably encouraged the use of acidophilus milk for constipation treatment whereas Bogdonovi G, et al., Reddy GV, Goldin BRaGL, Rowland IRG [83-86] found 
that L. Bulgaricus produced anti-carcinogenic substances. The anti-carcinogenic features of Lactobacilli have three categories:

- Tumor cells inhibition

- The suppression of bacteria which are responsible for the release of carcinogens

- The carcinogen destruction

Skimmed and fermented milk, feeding yogurt to humans produced lower blood cholesterol concentrations illustrated by Mann GV, Nair CRaMGV, Grunewald K, [77,87,88] whereas Vaginal Lactobacilli, or bifidobacteria protect the female urogenital tract from pathogen, thus playing a role in the maintenance of a healthy state, proposed by McCarthy DM, et al, Morishita T, et al, $[89,90]$. The figure summarizes the bio therapeutic agents of Lactobacilli given (Figure 1).

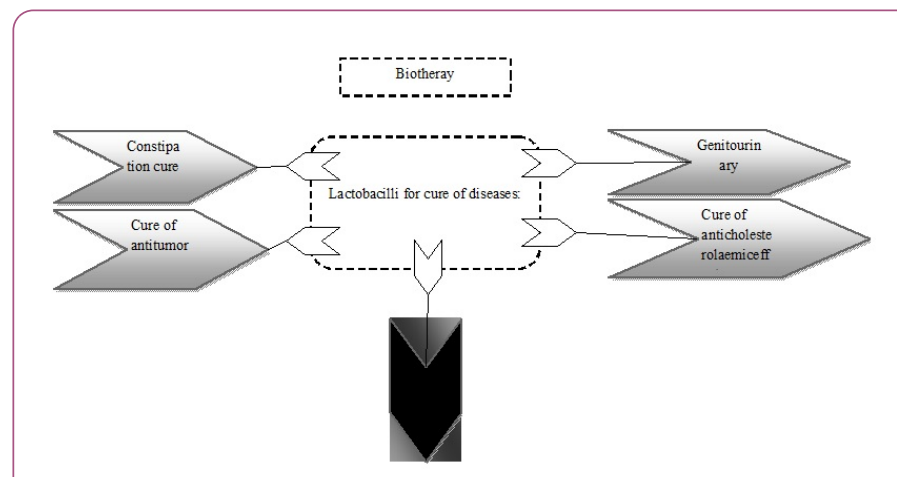

Figure 1 Bio-therapeutic agent.

\section{Lactobacilli strains and products}

Some of the Lactobacilli species in the industries are used in the manufacturing of beer, cocoa, kefir, sauerkraut, cheese, cider, kimchi, pickles, yogurt and other fermented food as well as animal feeds. The antifungal and antibacterial activity of species rely on bacteriocin production and low molecular weight compounds that inhibits these microorganisms activity moreover these bacteria metabolize sugars into lactic acid that lowers the $\mathrm{pH}$ of their environment [91].

The genus contains over 180 species and some important strains are L. acetotlerans, L. acidifarinae, L. acidipiscis, L. acidophilus, L. agilis, L. algidus, L. alimentarius, L. amylolyticus, L. amylophilus, L. amylotrophicus, L. amylovorus, etc. [91] (Figure 2).

\section{Safety for human beings}

Lactobacilli are generally used in probiotic production. Lactobacilli increases soon after the birth when gut flora has developed, as the other components of the flora decrease [92] similar in the case of pigs when Lactobacilli was supplemented in their food consequently $E$. coli got reduced in the stomach [93]. Experiments with chicks have proved the effect of Lactobacilli on E. coli colonization [17].

Probiotic Lactobacilli are appropriate for infants and children because several investigations have illustrated those products containing Lactobacilli and Bifidobacteria spp. are well tolerated in this age profile [94-96]. Food products containing such strains for infants generally are restricted to I-lactic acid producers [97]. There are also specific compositional legal requirements e.g., electrolyte loading and nutrient contents for food products $[98,99]$. Recently, there have been several documented case reports of fungemia that are associated with a Saccharomyces cerevisiae (yeast) probiotic due to indwelling catheters contamination [100]. Dietary carbohydrates and antibiotic therapy appear to be the most essential predisposing factors [101] (Figure 3).

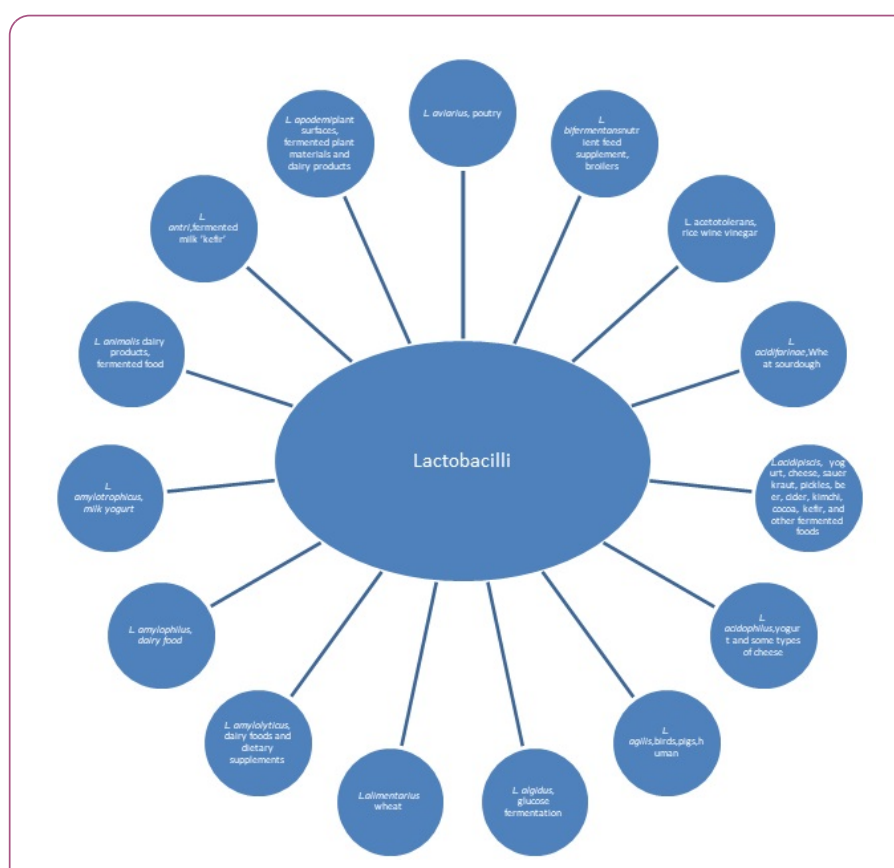

Figure 2 Lactobacilli strains and products.

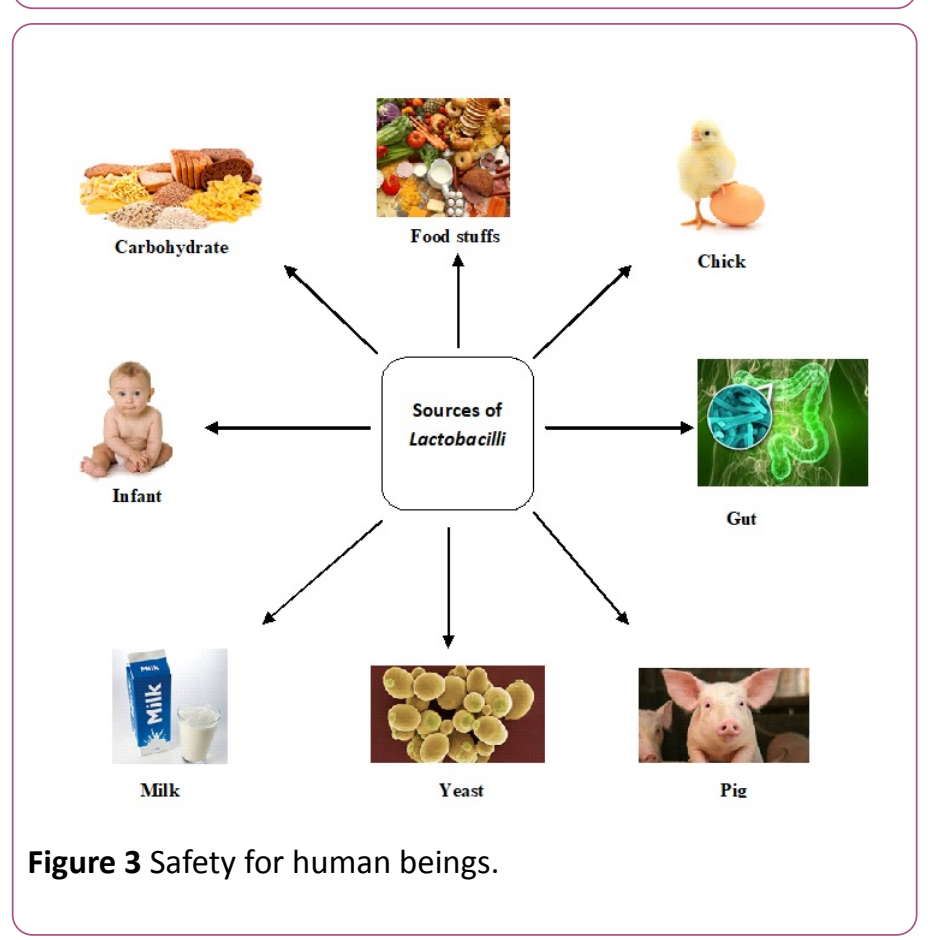




\section{Future perspectives}

Probiotic are recently recommended for dietary supplements. Future developments will discover more effective strains to bring together the ability to survive in the gut and to develop the metabolites, responsible for the probiotic effect. Recent work by McCarthy DM [89] suggests that these techniques are available. They showed that $L$. acidophilus isolated from pigs could be genetically transformed to colonize the mouse gastric epithelium. Although the technology is equipped but we still need to know more about the probiotic efficiencies. The current potential of this approach has been reviewed by Tannock GW [102-106].

\section{Conclusion}

Probiotics as biotherapeutic agent have already been started and in the coming future it is conceivable that they will become more effective tools in the treatment of different disorders like immune system stimulation, anti-mutagenic effects, cholesterol level fluctuations, diarrhea, oral and urinary tract infections (UTIs), vaginitis, lactosemal absorption etc. as an alternative or complement to other usual treatments. It is the natural treatment for rearing young animals and human babies as well as in nourishment and cure of disease therapy. Probiotic restore the natural balance of the animal growth, gut flora, health and nutrition status. Besides treatment, there usage in infant diet and milk is in now daily practice. At my suggestion, isolation of Lactobacilli from fermented sugar cane can be beneficial for regulating the liver enzymes. They can also be helpful in lowering the bilirubin level in dehydrated patients.

\section{References}

1. Pandya N (2007) Facts and comparisons 4.0. J Med Libr Assoc 95: 217-219.

2. Parvez S, Malik KA, Ah Kang S, Kim HY (2006) Probiotics and their fermented food products are beneficial for health. J Appl Microbiol 100: 1171-1185.

3. Heravi RM, Kermanshahi M, Sankian M, Nassiri MR, Moussavi AH, et al. (2011) Screening of lactobacilli bacteria isolated from gastrointestinal tract of broiler chickens for their use as probiotic. Afr J Microbiol Res 5: 1858-1868.

4. Sears J, William S, Sears M, Sears P (2011) The portable pediatrician: everything you need to Know about Your Child's Health. Little, Brown.

5. Sumarsih S, Sulisiyanto B, Sutrisno Cl, Rahayu ES (2014) Characteristic of isolated from pengging duck's intestines as probiotics. Int J Poult Sci 13: 47-51.

6. Ouwehand AC, Salminen S, Isolauri E (2002) Probiotics: an overview of beneficial effects. Antonie Van Leeuwenhoek 82: 279-289.

7. Food and Agriculture Organization of the United Nations (FAO) and World Health Organization (WHO) Health and nutritional properties of probiotics in food including powder milk with live lactic acid bacteria. 2004: FAO and WHO Joint and Expert Committee Report 2001.
8. Abulfazl B (2012) Isolation and molecular study of potentially probiotic lactobacilli in traditional white cheese of tabriz in iran. Ann Biol Res 3: 2213-2216.

9. Garriga P, Monfort, Hugas (1998) Selection of lactobacilli for chicken probiotic adjuncts. JABS 84:125-132.

10. Martin R, Heilig GJH, Zeotendal EG, Smidt H, JRodriguez JM (2007) Diversity of the group in breast milk and vagina of healthy women and potential role in the colonization of the infant gut. J Appl Microbiol 103: 2638-2644.

11. Martin R, Langa S, Reviriego C, Jimenez E, Marin ML, et al. (2004) The commensal microflora of human milk: new perspectives for food bacteriotherapy and probiotics. Trends Food Sci Technol 15: 121-127.

12. Martin R, Olivares M, María LM, Fernandez L, Xaus J et al. (2005) Probiotic Potential of 3 Lactobacilli Strains Isolated From Breast Milk. J Hum Lact 21.

13. Heikkila MP, Saris PEJ (2003) Inhibition of Staphylococcus aureus by the commensal bacteria of human milk. J Appl Microbiol 95:471-472.

14. Anandharaj M, Sivasankari B (2013) Isolation of potential probiotic strains from human milk. International Journal of Research in Pharmacy and Life Sciences 1: 26-29.

15. Martin R, Soberon N, Vaneechoutte $M$, Florez AB, Vazquez F, et al. (2008) Characterization of indigenous vaginal Lactobacilli from healthy women as probiotic candidates. Int Microbiol 11: 261-266.

16. Alvarez-Olmos MI, Oberhelman RA (2001) Probiotic agents and infectious diseases: a modern perspective on a traditional therapy. Clin Infect Dis 32: 1567-1576.

17. Fuller R (1976) Epithelial attachment and other factors controlling the colonization of the intestine of the gnotobiotic chicken by lactobacilli. J Appl Bacteriol 46: 335-342.

18. Kaila K, Chin J (2000) Survival and therapeutic potential of probiotic organisms with reference to Lactobacillus acidophilus and Bifidobacterium spp. Immunol Cell Biol 78: 80-88.

19. Kalui CM, Mathara JM, Kutima PM, Kiiyukia C, Wongo LE (2009) Functional characteristics of plantarumand rhamnosusfrom ikii, a Kenyan traditional fermented maize porridge. Afr J Biotechnol 8: 4363-4373.

20. Kaboosi H (2011) Antibacterial effects of probiotics isolated from yoghurts against some common bacterial pathogens. Afr J Microbiol Res 5: 4363-4367.

21. Lavanya B, Sowmiy A, Balaji S, Muthuvelan B (2011) Plasmid profiling and curing of strains isolated from fermented milk for probiotic applications. Adv J Food Sci Technol 3: 95-101.

22. Wang CY, Lin PR, Ng CC, Shyu YT (2010) Probiotic properties of strains isolated from the feces of breast-fed infants and Taiwanese pickled cabbage. Anaerobe 16: 578-585.

23. Chang S, Tsai C, Wee C, Yan T (2013) Isolation and functional study of potentially probiotic Lactobacilli from Taiwan traditional paocai. Afr J Microbiol Res 7: 683-691.

24. Abubakr M, Al-Adiwish WM (2017) Isolation and identification of lactic acid bacteria from different fruits with proteolytic activity. International Journal of Microbiology and Biotechnology 2: 58-64.

25. Suryavanshi MV, Paul D, Doijad SP, Bhute SS, Hingamire TB, et al. (2017) Draft genome sequence of plantarum strains E2C2 and E2C5 isolated from human stool culture. Stand Genomic Sci 12. 
26. El-Shenawy M, Dawoud El, Amin GA, El- Shafei K, Fouad MT, et al. (2017) Antimicrobial activity of some lactic acid bacteria isolated from local environment in Egypt. Afr J Microbiol Res 11: 327-334.

27. Tavakoli M, Hamidi-Esfahani Z, Amin M, Hejazi-Azizi MH, Abbasi S (2017) Characterization of probiotic abilities of lactobacilli isolated from iranian koozeh traditional cheese. Pol J Food Nutr Sci 67: 41-48.

28. Plessas S, Nouska C, Mantzourani I, Kourkoutas Y, Alexopoulos A, et al. (2017) Microbiological exploration of different types of kefir grains. Fermentation 3.

29. Ibourahema C, Dauphin RD, Jacqueline D, Thonart P (2008) Characterization of lactic acid bacteria isolated from poultry farms in Senegal. African Journal of Biotechnology 7: 2006-2012.

30. Oguntoyinbo FA, Cho GS, Brinks EB, Fiedler G, Kabisch J (2016) Draft Genome Sequence of Lactobacillus plantarum BFE 5092 Isolated from Maasai Fermented Milk. Genome Announc 4: e00481-16.

31. Eid R, ElJakee J, Rashidy A, Asfour H, Omara S, et al. (2016) Potential antimicrobial activities of probiotic strains isolated from raw milk. J Prob Health 4.

32. Shehataa MG, Sohaimya SA, El-Sahn MA, Youssef MM (2016) Screening of isolated potential probiotic lactic acid bacteria for cholesterol lowering property and bile salt hydrolase activity. Annals of Agricultural Science 61: 65-75.

33. Sornplang P, Piyadeatsoontorn S (2016) Probiotic isolates from unconventional sources: a review. J Anim Sci Technol 58: 26.

34. Martin R, Langa S, Reviriego C, Jimenez E, Marin ML, et al. (2003) Human milk is a source of lactic acid bacteria for the infant gut. J Pediatr 143: 754-758.

35. Lutful Kabir SM, Rahman M, Neogi SB; Rahman MM, Rahman Khan MS (2016) Isolation, identification, molecular characterization and screening of probiotic activities of species from poultry sources at live bird markets in Mymensingh, Bangladesh. Asian Australas J Biosci Biotechnol 1:54-65.

36. Abo-Sereih NA, El-Ghamery AA, AEl-Kawokgy TM, Sofy AR, Fikry AE (2016) Application of ISSR analysis for identification of lactic acid bacteria strains isolated from Egyptians milk products. Journal of Innovations in Pharmaceuticals and Biological Sciences 3:204-213.

37. Anacarsoi L Bassoli L, Sabia C, Lseppi R, Condo C (2015) Isolation and identification of lactic acid bacteria from plants and other vegetable matrices and microbial recombination with Enterococcus spp. American research thoughts 1.

38. Jose NM, Bunt CR, Hussain MA (2015) Comparison of microbiological and probiotic characteristics of lactobacilli isolates from dairy food products and animal rumen contents. Microorganisms 3: 198-212.

39. Masoumikia R, Ganbarov K (2015) Antagonistic activity of probiotic lactobacilli against human enteropathogenic bacteria in homemade tvorog curd cheese from Azerbaijan. Bioimpacts 5: 151-154.

40. Moslem MN, Lakeh MT, Lozoumi Z, Issapour F, Irani M (2014) Isolation, identification of probiotic Lactobacilli from traditional yogurts produced in rural areas of Mazandaran province (Northern Iran). AJBLS 3: 93.

41. Amraii HN, Abtahi $H$, Jafari $P$, Mohajerani $H R$, Fakhroleslam MR, et al. (2014) In vitro study of potentially probiotic lactic acid bacteria strains isolated from traditional dairy products. Jundishapur J Microbiol 7: e10168.
42. Noohi N, Rohani M, Talebi M, Pourshafie MR, Ebrahimipour G (2014) Phenotypic characteristics and probiotic potentials of spp. isolated from poultry. Jundishapur J Microbiol 7: e17824.

43. Tropchev R, Nikolova D, Evstatieva Y, Danova S (2014) Antifungal activity and identification of lactobacilli isolated from traditional dairy product "katak. Anaerobe 28: 78-84.

44. Rayes-Nava LA, Rivera-Espinozan Y (2014) Isolation sources of bile salt hydrolase-microorganisms. Herald Journal of Agriculture and Food Science Research 3: 049-054.

45. Acurcio LB, Souza MR, Nunes AC, Oliveira DLS, Sandes SHC, et al. (2014) Isolation, enumeration, molecular identification and probiotic potential evaluation of lactic acid bacteria isolated from sheep milk. Arq Bras Med Vet Zootec 66: 940-948.

46. Jeygowri N, Parahitiyawa N, Jayatilake S, Ranadheera S, Madhujith WMT (2014) Antimicrobial activity of potentially probiotic species isolated from fermented rice. International Research Sessions, Sri Lanka 18.

47. Ozyurt VH, Otles S (2014) Properties of probiotics and encapsulated probiotics in food. Acta Sci Pol Technol Aliment 13: 413-424.

48. Elsayed EA, Othman NZ, Malek R, Tang T, Enshasy HAE (2014) Improvement of cell mass production of delbrueckiisp bulgaricusWICC-B-02: A newly isolated probiotic strain from mother's milk. Journal of Applied Pharmaceutical Science 4: 008-014.

49. Kale PS (2014) Isolation and identification of bacteria from curd and its application in probiotic chocolate. Euro J Exp Bio 4:95-97.

50. Palacio MI, Etcheverria A Manrique GD (2014) Fermentation by paracasei of galactooligosachrides and low molecular weight carbohydrates extracted from squash (Curcubita maxima) and Lupin (Lupinus albus) seeds. J Microbiol Biotech Food Sci 3: 329-332.

51. Morandia S, Brascaa M, Andrighettob C, Lombardib A, Lodi R (2006) Technological and molecular characterization of enterococci isolated from north-west italian dairy products. Int Dairy J 16: 867-875.

52. Anderson AC, Sanunu M, Schneider C, Clad A, Karygianni L, Hellwig E, Al-Ahmad A (2014) Rapid species-level species-level identification of vaginal and oral lactobacilli using MALDI-TOF MS analysis and16S rNA sequencing. BMC Microbiol 14: 312.

53. Pyar H, Liong MT, Peh KK (2013) Potentials of pineapple waste as growth medium for species. International Journal of Pharmacy and Pharmaceutical Sciences 6.

54. Zeng Y, Lu Y, Wang J, Yang L, Pan C, Huang Y (2013) Probiotic properties of Lactobacillus strains isolated from Tibetan kefir grains. PLoS One 8: e69868.

55. Ramos CL, Thorsen L, Schwan RF, Jespersen L (2013) Strain-specific probiotics properties of Lactobacillus fermentum, plantarum and brevis isolates from Brazilian food products. Food Microbiol 36: 22-29.

56. Sanjeeb KM, Satya V (2013) Preliminary studies on probiotic potential of selected VITSSV strains screened from curd samples of vellore, bihar, haryana and Varanasi. Int J Pharm Bio Sci 4:193-200.

57. Hayek SA, Shahbazi A, Worku W, Ibrahim SA (2013) Enzymatic activity of Lactobacillus reuteri grown in a sweet potato based medium with the addition of metal ions. Springerplus 2: 465.

58. Denkova R, Denkova Z, Yanakieva V, Blazheva D (2013) Antimicrobial activity of probiotic lactobacilli, bifidobacteria and 
propionic acid bacteria, isolated from different sources. International Research Journal of Microbiology 5: 33-40.

59. Duary RK, Rajput YS, Batish VK, Grover S (2011) Assessing the adhesion of putative indigenous probiotic lactobacilli to human colonic epithelial cells. Indian J Med Res 134: 664-671.

60. Vidhyasagar V, Saraniya A, Jeevaratnam (2013) Identification of pectin degrading lactic acid bacteria from fermented food sources. Int J Adv Lif Sci 6.

61. Cunha AF, Acurcio LB, Assis BS, Oliveira DLS, Leite MO, et al. (2013) In vitro probiotic potential of spp. isolated from fermented milks. Arq Bras Med Vet Zootec 65: 1876-1882.

62. Chowdhury A, Hossain MN, Mostazir NJ, Fakruddin M, Billah MM, et al. (2012) Screening of spp. from buffalo yoghurt for probiotic and antibacterial activity. J Bacteriol Parasitol 3: 156.

63. Monteagudo-Mera A, Rodríguez-Aparicio L, Rua J, MartinezBlanco H, Navasa N, et al. (2012) In vitro evaluation of physiological probiotic properties of different lactic acid bacteria strains of dairy and human origin. Journal of functional foods 4 : 531-541.

64. Bhatt VD, Vidya YH, Kunjadia PD, Kunjadia AP (2012) Isolation and characterizaton of probiotic bacteria from human milk. IJPHC.

65. Shivram PL, Vishwanath PP (2012) Assessment of probiotic potential of $\mathrm{sp}$. isolated from cheese and preparation of probiotic ice-cream. IJRAP.

66. Kazemipoor M, Radzi CWJWM, Begum K and Yaze I (2012) Screening of antibacterial activity of lactic acid bacteria isolated from fermented vegetables against food borne pathogens. Archives Des Sciences.

67. Gueimonde M, Sánchez B, G de Los Reyes-Gavilán C, Margolles A (2012) Antibiotic susceptibility of probiotic bacteria. Front Microbiol 4: 202.

68. Yavuzdurmaz H, Sebnem H (2011) Selection of potential probiotic strains from human milk, in Food Product Engineering \&Functional Foods: 11th International Congress on Engineering and Food, Athens, Greece: Cosmoware 2043-2044.

69. Hoque MZ, Akter F, Hossain KM, Rahman MSM, Billah MM, et al. (2010) Isolation, identification and analysis of probiotic properties of spp. from selective regional yoghurts. World J Dairy \& Food Sci 5: 39-46.

70. Neville BA, O'Toole PW (2010) Probiotic properties of salivarius and closely related species. Future Microbiol 5: 759-774.

71. Kaushik JK, Kumar A, Duary RK, Mohanty AK, Grover S, et al. (2009) Functional and probiotic attributes of an indigenous isolate of plantarum. PLoS One 4: e8099.

72. Ryan KA, Jayaraman T, Daly P, Canchaya C, Curran S, et al. (2008) Isolation of lactobacilli with probiotic properties from the human stomach. Lett Appl Microbiol 47: 269-274.

73. Iñiguez-Palomares C, Pérez-Morales R, Acedo-Félix E (2007) Evaluation of probiotic properties in isolated from small intestine of piglets. Microbiologia 49: 46-54.

74. Aslim B, Kilic E (2006) Some probiotic properties of vaginal Lactobacilli isolated from healthy women. Jpn J Infect Dis 59: 249-253.

75. Weiss A, Lettner HP, Kramer W, Mayer HK, Kneifel W (2005) Molecular methods used for the identification of potentially probiotic reuteri strains. Food Technol Biotechnol 43: 295-300.
76. Succi M, Tremonte P, Reale A, Sorrentino E, Grazia L, et al. (2005) Bile salt and acid tolerance of rhamnosus strains isolated from Parmigiano Reggiano cheese. FEMS Microbiology Letters 244: 129-137.

77. Mann GV (1977) A factor of yoghurt which lowers cholesterolaemia in man. Atherosclerosis 26: 335-340.

78. Oyetayo VO, Osho B (2004) Assessment of probiotic properties of a strain of plantarum isolated from fermenting corn slurry (Ogi). JFAE 2: 132-134.

79. Ehrmann MA, Kurzak P, Bauer J, Vogel RF (2002) Characterization of lactobacilli towards their use as probiotic adjuncts in poultry. J Appl Microbiol 92: 966-975.

80. Cheplin HA, Rettger LF (1921) Studies on the transformation of the intestinal flora, with special reference to the implantation of bacillus acidophilus. I. Feeding Experiments with Albino Rats Proc NAS 6: 423-426.

81. Alm L, Humble D, Ryd-Kjellen E, Setterberg G (1983) The effect of acidophilus milk in the treatment of constipation in hospitalised geriatric patients. Symposia of the Swedish Nutrition Foundation (Sweden). Almqvistoch Wiksell International.

82. Graf W (1983) Studies on the therapeutic properties of acidophilus milk. Symposia of Swedish Nutrition Foundation. 15: 119-121.

83. Bogdonovi G, Popkhirstov P, Marinov L (1962) Anticancer effect of antibioticum bulgaricum on sarcoma 180 and on the select form of Ehrlich carcinoma Abstract VIII. International Cancer Congress 364.

84. Reddy GV, Shahani KM, Banerjee MR (1973) Inhibitory effect of the yoghurt on Ehrlich ascites tumor cell proliferation. J Natl Cancer Inst 50: 815-817.

85. Goldin B, Gorbach SL (1977) Alterations in fecal microflora enzymes related to diet, age, supplements and dimethyl hydrazine. Cancer 40: 421-426.

86. Rowland IR, Grasso P (1975) Degradation of N-nitrosamine by intestinal bacteria. Appl Microbiol 29: 7-12.

87. Nair CR, Mann GV (1977) A factor in milk which influences cholestermia in rats. Atherosclerosis 26: 363-367.

88. Grunewald KK (1982) Serum cholesterol levels in rats fed skim milk fermented by acidophilus. JFST 47: 2078-2079.

89. McCarthy DM, Lin JHC, Rinckel LA, Savage DC (1988) Genetic transformation in Lactobacilh ssp. Strain 100-33 of the capacity to colonize the nonsecreting gastric epithelium in mice. Appl Environ Microbiol 54: 416-422.

90. Morishita T, Deguchi Y, Yajima M, Saskurai T, Yura T (1981) Multiple nutritional requirements of lactobacilli: Genetic lesions affecting amino acid biosynthetic pathways. J Bacteriol 148: 64-71.

91. Inglin RC (2015) High-throughput screening assays for antibacterial and antifungal activities of species. J Microbiol Methods 114: 26-29.

92. Smith HW (1965) The development of the flora of the alimentary tract in young animals. J Pathol Bacteriol 90: 495-513.

93. Barrow PA, Brooker BE, Fuller R, Newport MJ (1980) The attachment of bacteria to the gastric epithelium of the pig and its importance in the micro-ecology of the intestine. J Appl Microbiol 48: 147-1 54. 
94. Cunningham-Rundles $S$, Ahrné $S$, Bengmark $S$, Johann-Liang $R$, Marshall F, et al. (2000) Probiotics and immune response. Am J Gastroenterol 95: S22-S25.

95. Pedone CA, Bernabeu AO, Postaire ER, Bouley CF, Reinert P (1999) The effect of supplementation with milk fermented by casei (strain DN-114 001) on acute diarrhoea in children attending day care centres. Int J ClinPract 53: p179-184.

96. Guandalini S, Zikri MA (2000) GG administered in oral rehydration solution to children with acute diarrhoea: a multicenter European trial. J Pediatr Gastro enterol Nutr 30: 54-60.

97. Codex Alimentarius Commission (1987) Codex Alimentariusx Codex standards for dietetique foods or diet foods, comprising foods destined for feeding of young infants, and a code relating to their hygienic utilisation. Geneva: World Health Organization.

98. Commission directive on infant formulae and follow-on formulae (1991) In: Official, in Journal of the European Communities. Luxemburg, Commission of the European Communities. L175: 35-49.

99. Commission directive on processed cereal-based foods and baby foods for infants and young children. In: Official. in Journal of the European Communities. 1996. Luxemburg City, Luxemburg: Commission of the European Communities: Publication 96/5/EC.

100. Hennequin C, Kauffmann-Lacroix C, Jobert A, Viard JP, Ricour C, et al. (2000) Possible role of catheters in Saccharomyces boulardiifungemia. Eur J ClinMicrobio Infect Dis 19: 16-20.
101. Vanderhoof JA, Young RJ, Murray N, Kaufman SS (1998) Treatment strategies for small bowel bacterial overgrowth in short bowel syndrome. J Pediatr Gastroenterol Nutr 27: 155-60.

102. Tannock GW (1988) Molecular genetics: a new tool for investigating the microbial ecology of the gastrointestinal tract. Microbial Ecology 15: 239-256.

103. Bao Y, Zhang Y, Zhang Y, Liu Y, Wang S, et al. (2010) Screening of potential properties of fermentum isolated from traditional dairy products. Food control 21: 695-701.

104. European Parliament and Council directive of 20 February 1995 on food additives other than colours and sweeteners., in In: Official Journal of the European Communities. 1995, Publication 95/2/EC.: Luxemburg City, Luxemburg: Commission of the European Communities.

105. Gilliland SE, Nelson CR, Maxwell C (1985) Assimilation of cholesterol by Lactobacillus acidophilus. Appl Environ Microbiol 49: 377-381.

106. Conway PL, Gorbach SL, Goldin BR (1989) Survival of lactic acid bacteria in the human stomach and adhesion to intestinal cells. J Dairy Sci 70: 1-12. 